\title{
制振部材を用いた鉄骨造体育館における屋根面架構の耐震性能 SEISMIC PERFORMANCE OF ROOF STRUCTURE IN STEEL GYMNASIA WITH ENERGY DISSIPATION DEVICES
}

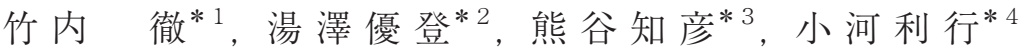 \\ Toru TAKEUCHI, Masato YUZAWA, Tomohiko KUMAGAI \\ and Toshiyuki OGAWA
}

\begin{abstract}
A number of school gymnasia in Japan exhibited or lead one to foresee insufficient seismic performance, and seismic retrofits on them are still underway throughout the country. However, current assessment practices often require the replacement or addition of roof braces, which are very time and cost consuming. Energy dissipating retrofits are better suited than common strength-based retrofits to help reduce excited vibration of the roof and burden of the roof braces and ceilings, however, optimum design and evaluation methods remain unclear. This paper investigates retrofit design using elasto-plastic or viscous dampers, discussing its effects on response reduction for roof braces and practical response estimation methods, followed by proposing the retrofit method which achieves required seismic performances without replacing the roof braces.
\end{abstract}

Keywords : School gymnasium, Seismic retrofit, Roof brace, Elasto-plastic damper, Viscous damper 学校体育館，而震改修，屋根面ブレース，弾塑性ダンパー，粘性ダンパー

\section{1. 序}

学校体育館における屋根面ブレースは，屋根面を一体化し，架構 に働いた水平地震荷重を各通りの鉛直構面に伝達させる役割をもつ。 本部位は過去の地震被害において座屈, 破断等の被害が数多く見ら れる箇所でもあり，文献 1) 2)では耐震診断に伴う学校体育館の屋 根面ブレースの検定手法が示されている。これらの検定により荷重 伝達性能が不足していると判断された場合には, 同基準を満たすた めに補強改修を実施することが要求される。しかし，保有耐力計算 における屋根面ブレースのモデル化の方法や，屋根面ブレースの塑 性化が主架構の耐震性能へ与える影響等, 残された課題は多く, 多 くの研究 ${ }^{3-9)}$ による取り組みが続いている。

現在の学校体育館の耐震改修においては, 強度型の鉛直ブレース を妻面や桁面に付加することで耐力, 剛性を高める手法が一般的と なっている。しかし, 本改修手法は屋根面ブレースの必要伝達力を 増加させるとともに, 下部構造の剛性増加による屋根面応答の増幅 も懸念されるため, 結果的に屋根面ブレースの補強改修を伴うこと が多い。屋根面ブレースの補強改修は屋内に総足場を組み, 既存架 構に上向き溶接でブレース部材を取り付ける必要がある等, 鉛直ブ レースのみの付加, 交換に比べ多大な労力と費用を要する。屋根面 ブレースへの負担を軽減させるためには, 強度型の改修手法よりも 制振部材を導入することで地震エネルギーを吸収する制振改修手法
が適していると考えられる。さらに，天井，照明等の非構造部材の 健全性を保持し，学校体育館を震災時の周辺地域の避難拠点として 継続利用可能と寸る観点からも，制振部材による応答低減効果は有 効であると考えられる ${ }^{10)}$ 。しかし，現在使用されている耐震指標 の簡便な評価手法が確立していないため，その実施例は未だほとん ごないのが現状である。これに対し筆者らは前論文 11)で典型的な 学校体育館の設計例をもとに, 制振改修, 強度型改修を含む耐震改 修手法の違いが屋根部の応答に与える影響を検証し，制振部材を用 いた改修に対する簡便な構造耐震指標の評価手法を提案し, その妥 当性を検証した。しかしながらこれらの検討では屋根ブレースは弾 性域に留まるものと仮定して検証を行った。

本研究では，学校体育館における屋根面ブレースの塑性化が主架 構の耐震性能に与える影響を分析し, 既往の強度型改修手法に加え 各種の制振改修手法において屋根面架構に要求される必要耐震性能 の分析，評価を行う。また，下部構造による屋根部の応答増幅およ び制振部材による応答低減効果を考慮した屋根面の必要伝達荷重の 簡便な評価手法の提案を行う。さらに得られた評価手法を用いて制 振部材の剛性および降伏変形の最適化を行い，既存の屋根面ブレー スを補強，交換すること無く鉛直ブレースの交換のみで構造部材お よび非構造部材に対する耐震性能を満足させ，震災後の継続利用を 可能と寸る制振改修手法の可能性について検討を行う。

\footnotetext{
*1 東京工業大学理工学研究科建築学専攻 教授 - 博士 (工学)

*2 元 東京工業大学理工学研究科建築学専攻 大学院生

*3 東京工業大学理工学研究科建築学専攻 助教 - 博士 (工学)

*4 東京工業大学理工学研究科建築学専攻 教授. 工博
}

Prof., Dept. of Arch. and Build. Eng., Tokyo Institute of Technology, Dr. Eng. Former Graduate Student, Dept. of Arch. and Build. Eng., Tokyo Institute of Technology Assistant Prof., Dept. of Arch. and Build. Eng., Tokyo Institute of Technology, Dr. Eng. Prof., Dept. of Arch. and Build. Eng., Tokyo Institute of Technology, Dr. Eng. 


\section{2. 検討モデルの設定}

本研究で対象とする架構は前論文 ${ }^{11)}$ と同様, 下層 $\mathrm{RC}$ 造, 上層 $\mathrm{S}$ 造の 1970 年代に設計された一般的な学校体育館を想定し, 梁間 $32 \mathrm{~m}$ 桁行 $42 \mathrm{~m}$ のトラス架構とする。部材断面は固定荷重に対する ベースシア係数 0.2 の許容応力度設計により決定する。固定荷重は 構造材重量および仕上げ材重量を考慮し, 屋根荷重 $1.0 \mathrm{kN} / \mathrm{m}^{2}$, 下 層壁荷重 $5.3 \mathrm{kN} / \mathrm{m}^{2}$, 上層壁荷重 $0.6 \mathrm{kN} / \mathrm{m}^{2}$ と寸る。屋根形状は切妻 屋根とし, 同一スパンの半開角 $\theta=30^{\circ}$ の円筒シェルとライズが等し くなるよう屋根勾配を設定する。図 1 に対象架構, 表 1 に部材諸元 を示す。図 1 に示寸ように梁間方向構面をX1～X8, 桁行方向構面 をY1〜Y5 と表記する。

既存架構の解析モデルを無補強モデルとし，無補強モデルの妻面， 桁面に剛強な鉛直ブレースを付加した強度型補強モデル，各種制振 部材を付加した制振補強モデルを設定する。制振部材はブレース形 式とし，弾塑性ダンパーおよび粘性ダンパーの 2 種類を使用する。 無補強モデル, 強度型補強モデルの鉛直ブレースは、座屈を考慮し 柴田・若林らの手法 ${ }^{12), 13)}$ でモデル化する。弾塑性ダンパー付加モ デルはバイリニア型弾塑性要素を付加し, 粘性ダンパー付加モデル は線形粘性要素を付加する。さらに各モデルにおいて, 屋根面ブ レースは補強前後で 2 種類の断面を設定する。既存屋根面ブレース は丸鋼 $\phi 16$ とし, 交換後の改修屋根面ブレースは山型鋼 L-50×50×6 と寸る。屋根面ブレースは, 圧縮には抵抗せず引張にのみ抵抗する ものとし, 履歴特性を弾性およびスリップ型弾塑性の 2 種類でモデ ル化する。解析モデルを図 2, モデル名の定義を図 3 に示寸。

無補強モデルと強度型補強モデルについて, 文献 1)に基づき耐 震診断を行った結果を表 2 に示す。無補強モデルは梁間方向, 桁行 方向ともに $I_{S}$ 值が慣用的な要求水準 $\left(I_{S O}=0.7\right)$ を満たさず，耐震 性能が不足したモデルとなっている。強度型補強モデルは梁間方向, 桁行方向ともに同要求水準を満たしている。なお、無補強モデルの 鉛直ブレースは非保有水平耐力接合を有する勒性指標 $\mathrm{F}=1.3$ 相当を 想定しているが、履歴に破断は考慮しない。

表 3 に制振部材パラメータを示す。弾塑性ダンパーは低降伏点鋼 $\left(\sigma_{y}=100 \sim 200 \mathrm{~N} / \mathrm{mm}^{2}\right)$ を用いたブレース型履歴ダンパーを想定し， 主架構に対するダンパーの剛性比 $K_{d} / K_{f}$ を梁間方向で $0.5 \sim 2.0$, 桁 行方向で $10 \sim 30$, 降伏層間変形角 $\phi_{d v}$ を $1 / 1000 \sim 1 / 500$ と変化させ る。これらの弾塑性ダンパーの降伏せん断力 $Q_{d y}$ は上層重量 $W_{2}$ に 対し $0.1 \sim 0.4$ 倍程度となる。粘性ダンパーはブレース型線形粘性 ダンパーを想定し，等価減衰定数 $h_{e q}$ を $0.1 \sim 0.4$ と変化させる。

まず，屋根面の負担が最も大きい強度型補強モデルにおいて, 略 算法 ${ }^{1)}$ に基づき式(1)の水平震度 $K_{n}$ を屋根面に作用させ弾性解析を 行う。

$$
K_{n}=I_{s o} \cdot F_{e s i} \cdot A_{i} / F_{i}
$$

ここに， $F_{e s i}$ は剛性率および偏心率によって定まる係数， $A_{i}$ は層 せ 几断力係数の高さ方向の分布を表す係数, $F_{i}$ は $i$ 層の勒性指標であ る。ただし， $K_{n} \geq 0.55 \cdot A_{i} \cdot F_{e s i}$ とする。

屋根面の剛性は屋根面ブレースのみを考慮し, 屋根面全体が下部構 造の水平剛性ばねにより支持されたモデルにより屋根面伝達荷重を 評価した。屋根面ブレースの耐力検定結果を表 4 に示寸。既存屋根 面ブレースは梁間方向, 桁行方向ともに耐力が不足しており, 梁間

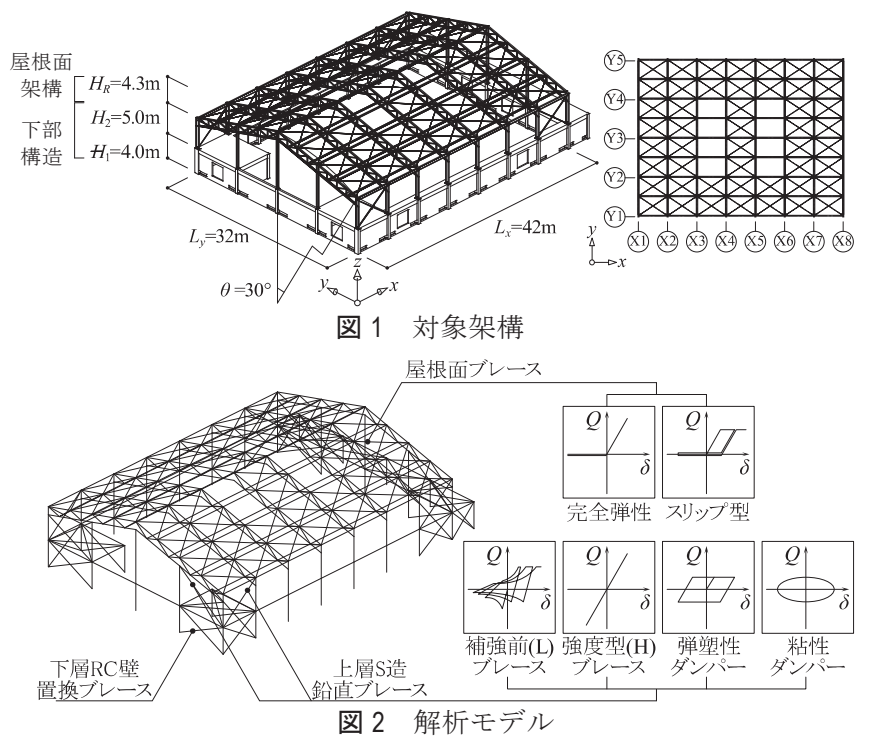

$\mathrm{FA}_{\underline{H}}-\underline{0.5}-\underline{1000}-\mathrm{B}_{\mathrm{E}}$

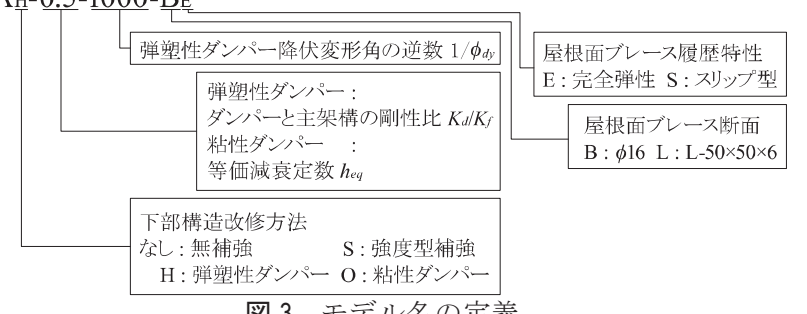
図 3 モデル名の定義

表 1 部材諸元

\begin{tabular}{|c|c|c|c|c|c|c|}
\hline \multirow[b]{2}{*}{ 部材名 } & \multicolumn{2}{|l|}{ 想定部材 } & \multicolumn{4}{|c|}{ 解析モデル } \\
\hline & 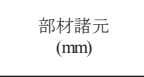 & $\left|\begin{array}{c}\text { 細長比 } \\
\lambda\end{array}\right|$ & $\begin{array}{l}\text { 断面積 } \\
A\left(\mathrm{~cm}^{2}\right)\end{array}$ & $\begin{array}{c}\text { 断面2次 } \\
\text { モーメント } \\
I\left(\mathrm{~cm}^{4}\right)\end{array}$ & $\begin{array}{c}\text { 降伏応力度 } \\
\sigma_{y}\left(\mathrm{~N} / \mathrm{mm}^{2}\right)\end{array}$ & $\begin{array}{l}\text { ヤング率 } \\
E\left(\mathrm{~N} / \mathrm{mm}^{2}\right)\end{array}$ \\
\hline 弦材 & $2 \mathrm{~L}-150 \times 150 \times 15$ & 91 & 85.5 & 1776 & \multirow{10}{*}{235} & \multirow{10}{*}{$2.05 \times 10^{5}$} \\
\hline 斜材 & $2 \mathrm{~L}-75 \times 75 \times 12$ & 119 & 33.1 & 164 & & \\
\hline 小梁 & $2 \mathrm{~L}-130 \times 130 \times 15$ & 153 & 73.5 & 1136 & & \\
\hline 枌梁 & $\mathrm{H}-400 \times 200 \times 8 \times 13$ & 132 & 83.4 & 23500 & & \\
\hline 鉄骨柱(桁面) & $\mathrm{H}-500 \times 200 \times 10 \times 16$ & 115 & 112 & 46800 & & \\
\hline 鉄骨柱 (妻面) & $\mathrm{H}-350 \times 175 \times 7 \times 11$ & 205 & 62.9 & 984 & & \\
\hline 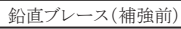 & $\mathrm{L}-75 \times 75 \times 6$ & 340 & 8.73 & 46.1 & & \\
\hline 鉛直ブレース(強度型) & $\mathrm{H}-200 \times 200 \times 8 \times 12$ & 156 & 63.5 & 4720 & & \\
\hline 既存屋根面ブレース & $\phi 16$ & 1823 & 2.01 & 0.32 & & \\
\hline 改修屋根面ブレース & L-50×50×6 & 486 & 5.64 & 12.6 & & \\
\hline RC梁 & $250 \times 600$ & 69 & 1500 & $1.25 \times 10^{6}$ & \multirow{3}{*}{ 完全弾性 } & \multirow{3}{*}{$2.00 \times 10^{4}$} \\
\hline RC柱(桁面) & $400 \times 700$ & 35 & 2800 & $1.14 \times 10^{6}$ & & \\
\hline RC柱(妻面) & $400 \times 400$ & 35 & 1600 & $2.13 \times 10^{5}$ & & \\
\hline
\end{tabular}

表 $2 I_{S}$ 值評価

\begin{tabular}{|c|c|c|c|c|c|c|c|c|c|c|}
\hline & \multicolumn{5}{|c|}{ 梁間方向 (上下層) } & \multicolumn{5}{|c|}{ 桁行方向 (上層) } \\
\hline & $Q_{f u}(\mathrm{kN})$ & $W(\mathrm{kN})$ & $C$ & $F$ & $I_{S}$ & $Q_{f u}(\mathrm{kN})$ & $W_{2}(\mathrm{kN})$ & $C$ & $F$ & $I_{S}$ \\
\hline 無補強モデル & 2220 & \multirow{2}{*}{2796} & 0.53 & \multirow{2}{*}{1.3} & 0.69 & 630 & \multirow{2}{*}{1696} & 0.16 & \multirow{2}{*}{1.3} & 0.21 \\
\hline 強度型補強モデル & 5926 & & 1.41 & & 1.84 & 5462 & & 1.42 & & 1.84 \\
\hline
\end{tabular}

$Q_{f u}$ : 保有水平耐力 $C$ : 強度指標 $=Q_{f u} /\left(F_{e s} \cdot Z \cdot R_{f} \cdot A_{i} \cdot \Sigma W_{i}\right) \quad F$ : 勒性指標 $\quad W i: i$ 層の重量 $F_{e s}=1.5 A_{2}=1.52$ (桁行方向、 $W_{1}=3813 \mathrm{kN}, W_{2}=1696 \mathrm{kN}$ )

表 3 制振部材パラメータ

\begin{tabular}{|c|c|c|c|c|c|c|}
\hline モデル名 & $\begin{array}{l}Q_{d y} \\
(\mathrm{kN})\end{array}$ & $K_{d} / K_{f}$ & $\begin{array}{c}T_{1} \\
(\mathrm{sec})\end{array}$ & $\begin{array}{c}K_{1} \\
(\mathrm{kN} / \mathrm{mm})\end{array}$ & $\begin{array}{c}T_{2} \\
(\mathrm{sec})\end{array}$ & $\begin{array}{c}K_{2} \\
(\mathrm{kN} / \mathrm{mm})\end{array}$ \\
\hline $\mathrm{FA}_{\mathrm{H}-0.5-1000}$ & 171 & \multirow{3}{*}{0.5} & \multirow{3}{*}{0.28} & \multirow{3}{*}{86.0} & \multirow{5}{*}{0.35} & \multirow{6}{*}{57.4} \\
\hline FAн-0.5-750 & 228 & & & & & \\
\hline FАн-0.5-500 & 341 & & & & & \\
\hline FАн-1-1000 & 341 & \multirow{2}{*}{1.0} & \multirow{2}{*}{0.24} & \multirow{2}{*}{114.7} & & \\
\hline $\mathrm{FA}_{\mathrm{H}}-1-750$ & 455 & & & & & \\
\hline $\mathrm{FA}_{\mathrm{H}}-2-1000$ & 683 & 2.0 & 0.20 & 172.1 & & \\
\hline
\end{tabular}

(粘性ダンパー)

(b)桁行方向 (弾塑性ダンパー)

\begin{tabular}{|c|c|c|c|c|c|c|}
\hline モデル名 & $\begin{array}{l}Q_{d y} \\
(\mathrm{kN})\end{array}$ & $K_{d} / K_{f}$ & $\begin{array}{c}T_{1} \\
(\mathrm{sec})\end{array}$ & $\begin{array}{c}K_{1} \\
(\mathrm{kN} / \mathrm{mm})\end{array}$ & $\begin{array}{c}T_{2} \\
(\mathrm{sec})\end{array}$ & $\begin{array}{c}K_{2} \\
(\mathrm{kN} / \mathrm{mm})\end{array}$ \\
\hline FAн-10-750 & 307 & & & & \multirow{6}{*}{1.22} & \multirow{6}{*}{4.60} \\
\hline $\mathrm{FA}_{\mathrm{H}}-10-500$ & 460 & & & 50.6 & & \\
\hline FАн-20-1000 & 460 & \multirow{3}{*}{20} & \multirow{3}{*}{0.27} & \multirow{3}{*}{96.6} & & \\
\hline FAн-20-750 & 614 & & & & & \\
\hline FAн-20-500 & 920 & & & & & \\
\hline $\mathrm{FA}_{\mathrm{H}}-30-1000$ & 690 & 30 & 0.22 & 142.6 & & \\
\hline
\end{tabular}

（粘性ダンパー）

\begin{tabular}{|c|c|c|}
\hline モデル名 & $h_{e q}$ & $\begin{array}{c}C_{d} \\
(\mathrm{kNsec} / \mathrm{mm})\end{array}$ \\
\hline FAo-0.1 & 0.1 & 46 \\
\hline FAo-0.2 & 0.2 & 105 \\
\hline FAo- 0.4 & 0.4 & 221 \\
\hline
\end{tabular}


表 4 屋根面ブレースの耐力検定結果

(a) 梁間方向

\begin{tabular}{|c|c|c|c|c|c|c|c|c|}
\hline & & $\mathrm{X} 1-\mathrm{X} 2$ & $\mathrm{X} 2-\mathrm{X} 3$ & $\mathrm{X} 3-\mathrm{X} 4$ & $\mathrm{X} 4-\mathrm{X} 5$ & $\mathrm{X} 5-\mathrm{X} 6$ & $\mathrm{X} 6-\mathrm{X} 7$ & $\mathrm{X} 7-\mathrm{X} 8$ \\
\hline \multirow{3}{*}{$\begin{array}{c}\text { 既存屋根面ブレース } \\
\phi 16\end{array}$} & 伝達荷重(kN) & 199 & 135 & 54 & 4 & 46 & 121 & 230 \\
\hline & 耐力(kN) & 215 & 215 & 107 & 215 & 107 & 215 & 215 \\
\hline & 検定値 & 0.93 & 0.63 & 0.51 & 0.02 & 0.43 & 0.57 & 1.07 \\
\hline \multirow{3}{*}{$\begin{array}{c}\text { 改修屋根面ブレース } \\
\text { L-50×50×6 }\end{array}$} & 伝達荷重(kN) & 320 & 218 & 101 & 4 & 93 & 208 & 343 \\
\hline & 耐力(kN) & 602 & 602 & 301 & 602 & 301 & 602 & 602 \\
\hline & 検定值 & 0.53 & 0.36 & 0.33 & 0.01 & 0.31 & 0.35 & 0.57 \\
\hline
\end{tabular}

(b) 桁行方向

\begin{tabular}{|c|c|c|c|c|c|c|c|c|c|}
\hline & & & & & & & & & \\
\hline \multirow{3}{*}{$\begin{array}{c}\text { 既存屋根面ブレース } \\
\phi 16\end{array}$} & 伝達荷重 $(\mathrm{kN})$ & 577 & 417 & 254 & 86 & 86 & 254 & 417 & 577 \\
\hline & 耐力(kN) & 272 & 272 & 194 & 194 & 194 & 194 & 272 & 272 \\
\hline & 検定值 & 2.12 & 1.53 & 1.30 & 0.44 & 0.44 & 1.30 & 1.53 & 2.12 \\
\hline \multirow{3}{*}{$\begin{array}{c}\text { 改修屋根面ブレース } \\
\text { L- } 50 \times 50 \times 6\end{array}$} & 伝達荷重 $(\mathrm{kN})$ & 577 & 417 & 254 & 86 & 86 & 254 & 417 & 577 \\
\hline & 耐力(kN) & 764 & 764 & 545 & 545 & 545 & 545 & 764 & 764 \\
\hline & 検定値 & 0.76 & 0.55 & 0.47 & 0.16 & 0.16 & 0.47 & 0.55 & 0.76 \\
\hline
\end{tabular}

※耐力不足の検定值を灰色で示す。

方向では下屋の地震層せん断力が加わる X7-X8 構面間, 桁行方向 では棟部周辺を除く大部分で耐力が不足している。改修屋根面ブ レースは, 梁間方向, 桁行方向ともに同要求水準を満たしている。

\section{3. 屋根面架構の地震応答特性}

鉛直荷重による幾何非線形性を考慮した固有值解析を行い, 得ら れた補強前モデルの卓越固有モードを有効質量比, 固有周期と併せ て図 4 に示寸。梁間方向, 桁行方向ともに屋根面架構の逆対称 1 波 と下部構造の 1 次モードが連成するモードが卓越する。

各モデルに対し幾何非線形性を考慮した時刻歴応答解析を行い, 下部構造の改修手法および屋根面改修の有無による屋根面応答性状 への影響の分析を行う。入力地震波は人工地震波 BCJ-L2 とし, 梁 間方向および析行方向に入力する。地震波の継続時間は 60 秒とする。 目標スペクトルは, レベル 2 の水平動規準化応答スペクトル ${ }^{14)} に$ 減衰による応答低減率 $D_{h}{ }^{15)}$ を乗じた式(2)，(3)で表されるモデル化 方向 加速度応答スペクトル BRI-L2 とする。

$$
\begin{aligned}
& S_{A}(T)= \begin{cases}350 D_{h} & (T<0.05) \\
350 D_{h}(T / 0.05)^{\{1+\log (5 / 7) / 2 \log 2\}} & (0.05 \leq T<0.2) \\
1000 D_{h} & (0.2 \leq T<\pi / 5) \\
100 D_{h} /(T / 2 \pi) & (\pi / 5 \leq T)\end{cases} \\
& D_{h}=\sqrt{\frac{\left(1+\alpha h_{r}\right)}{\left(1+\alpha h_{0}\right)}} \quad(\alpha=75)
\end{aligned}
$$

$T$ は固有周期 $(\mathrm{sec}), h_{r}=0.05, h_{0}$ は対象架構の減衰定数である。 図 5 に $h_{0}=0.2$ における BCJ-L2 の加速度応答スペクトルを BRI-L や他の観測波位相と共に示寸。本入力は建築基準法告示に示された 極稀に発生する設計用地震動を工学的基盤に与え, 短周期領域 $(0.2 \sim 0.6 \mathrm{sec})$ での表層地盤による増幅率を 1.72 に設定したレベル に相当し、概水 2 種地盤の 2 次設計入力に対応寸る。

図 6 に既存屋根面ブレースにおける補強前モデル, 強度型補強モ デルの屋根構面間せん断力 - 変形関係を示す。梁間方向, 桁行方向 ともに強度型補強を施したことで伝達荷重の増加, 塑性変形の進行 等, 屋根面架構への負担の増加が見られる。このように, 下部構造 に強度型補強を行ったことで屋根面ブレースの補強も必要となるこ とが分かる。図 7 に強度型補強モデルにおける屋根面の補強前後で の鉛直ブレース追加構面の層せん断力 - 変形関係を示す。無補強屋 根面ブレース $\phi 16$ は塑性化により荷重伝達がなされず，端部鉛直架 構の負担せん断力は低い。一方, 屋根面ブレースを改修し L-50 に交 換することで，端部架構の負担せん断力は増加することがわかる。

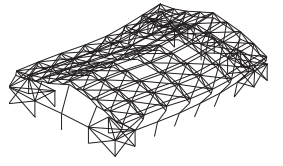

$39.06 \%, 0.392 \mathrm{sec}$

(a) 梁間方向

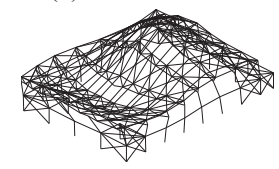

$17.74 \%, 0.460 \mathrm{sec}$

(b) 桁行方向

図 4 卓越固有モード

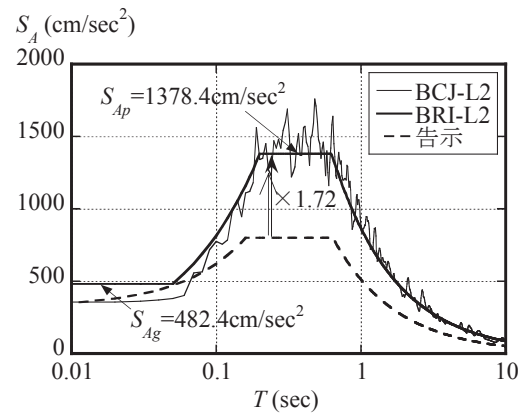

図 5 応答スペクトル $(h=0.02)$

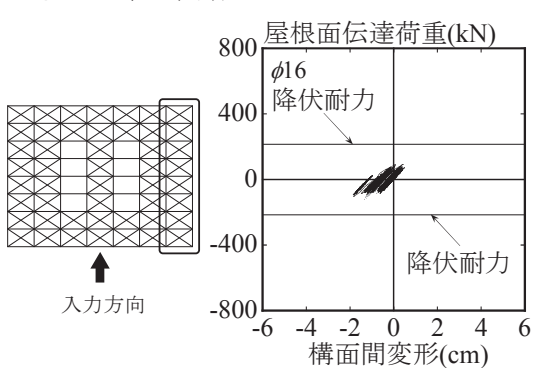

(a-1) FA-B S (補強前)

(a) 梁間方向

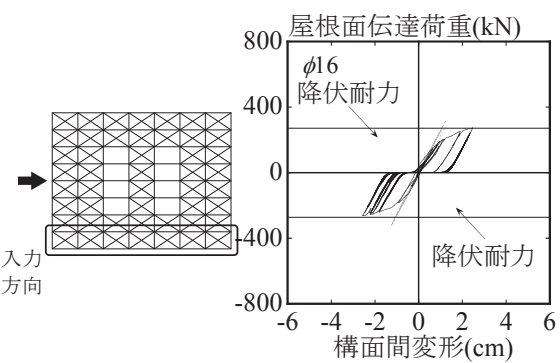

(b-1) FA-B （補強前）

(b) 桁行方向

図 6 屋根構面間せん断力

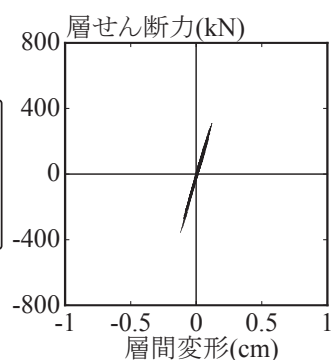

(a-1) $\quad \mathrm{FA}_{\mathrm{S}}-\mathrm{B}_{\mathrm{S}}(\phi 16)$

(a) 梁間方向

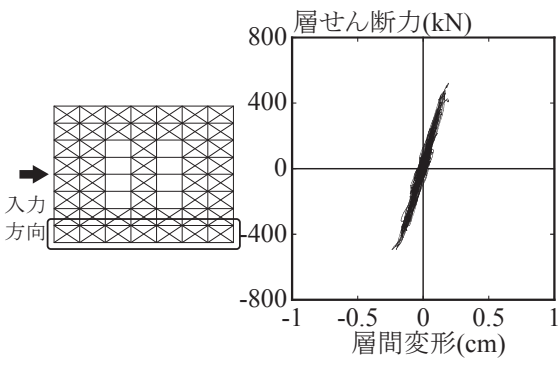

(b-1) $\mathrm{FA}_{\mathrm{S}}-\mathrm{B}_{\mathrm{S}}(\phi 16)$

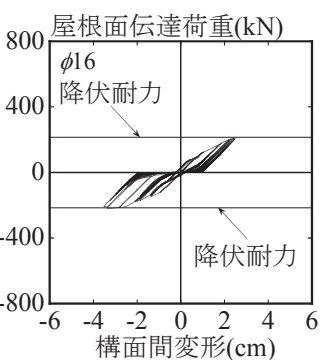

(a-2) $\mathrm{FA}_{\mathrm{S}}-\mathrm{B}_{\mathrm{S}}$ (強度型)

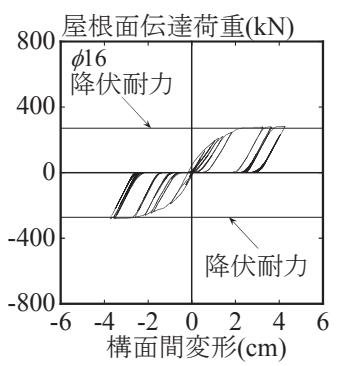

(b-2) $\mathrm{FA}_{\mathrm{S}}-\mathrm{B}_{\mathrm{S}}$ （強度型）

変形関係

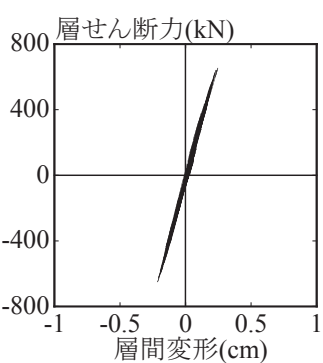

(a-2) $\mathrm{FA}_{\mathrm{S}}-\mathrm{L}_{\mathrm{S}} \quad(\mathrm{L}-50)$

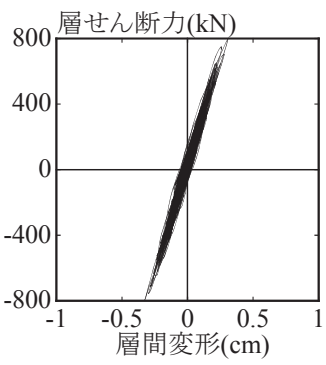

(b-2) $\mathrm{FA}_{\mathrm{S}}-\mathrm{L}_{\mathrm{S}}(\mathrm{L}-50)$
図 7 鈶直ブレース構面せん断力 - 変形関係 
図 8 に屋根ブレースをそのままで弾性, または弾塑性スリップモ デルとし, 強度型補強したモデルの最大屋根構面間変形角の分布お よび下部構造の最大層間変形角の分布を示す。桁行方向は屋根面ブ レースの塑性変形が進行することで屋根構面間の変形角は $1 / 100$ 以 上に増加し，屋根仕上げの損傷が予想される。また，構面間変形角 の増加に伴い中央棟部の層間変形角も $1 / 40$ 以上となる。梁間方向 は, 構面間全ての屋根面ブレースが塑性化した X7-X8 構面間での み変形角の増加が見られ, それ以外では屋根面ブレースの塑性化が 見られるものの構面間変形角の増加はあまり見られない。従って,
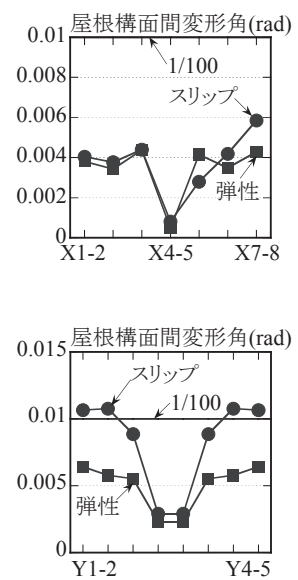

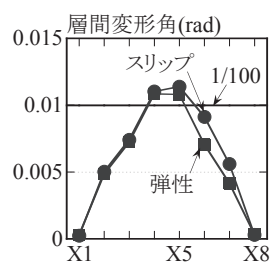

(a) 梁間方向

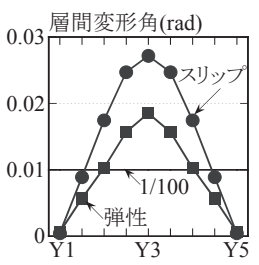

(b) 桁行方向

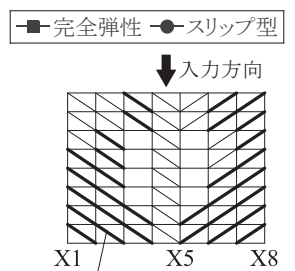

$\mathrm{X} 1$ 降伏したブレース

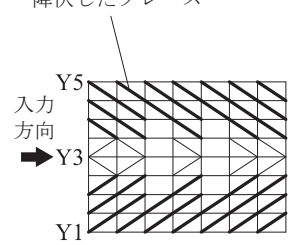

図 8 最大屋根構面間変形角分布と最大層間変形角分布 $\left(\mathrm{FA}_{\mathrm{S}}-\mathrm{B}_{\mathrm{E}}\right)$
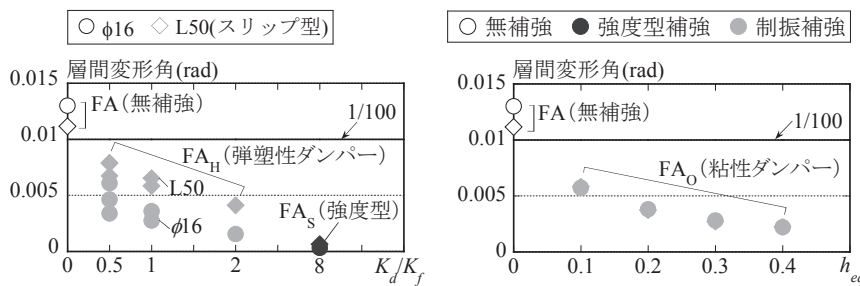

(a) 梁間方向
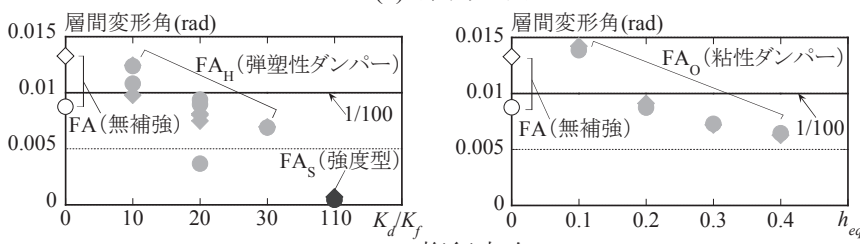

(b) 桁行方向

図 9 層間変形角の推移
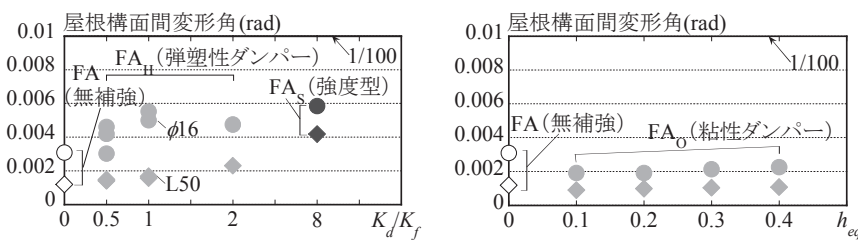

(a) 梁間方向
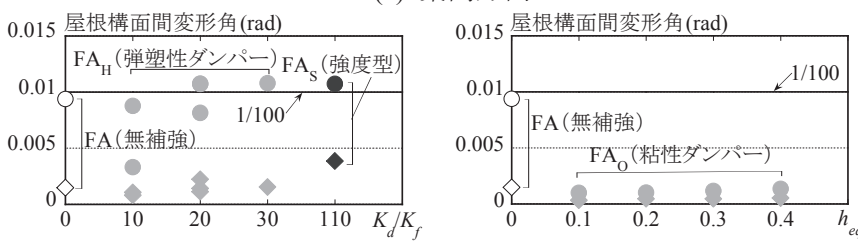

(b) 桁行方向

図 10 屋根構面間変形角の推移
屋根面ブレースの塑性化による影響は桁行方向でより顕著となる。 弾塑性ダンパー剛性比 $K_{d} / K_{f}$ および粘性ダンパー等価減衰定数 $h_{e q}$ に対する最大層間変形角の推移を図 9 に示す。なお同図中では強度 型ブレースを降伏しない弾塑性ダンパーとして弾塑性ダンパーの延 長線上の $K_{d} / K_{f}$ でプロットしている。層間変形角は弾塑性ダンパー, 粘性ダンパーともにダンパー量を大きくすることで低減される。ダ ンパー量に対する最大屋根構面間変形角の推移を図 10 に示す。屋 根構面間変形角は粘性ダンパーで補強前に比べ低減されるが, 弾塑 性ダンパーではダンパー量を大きくすることでかえって増加する傾 向が見られる。

壁面，屋根面ともに文献 16)より被災度判定が小破となる変形角 1/100 を限界変形量に設定すると，既存ブレースを改修しない状態 であっても梁間方向は全ての制振補強モデルで限界変形量以下とな る。桁行方向は, 弾塑性ダンパーが $K_{d} / K_{f}=20$ の $\phi_{d y}=1 / 1000$ のとき のみ, 粘性ダンパーが $h_{e q} \geqq 0.2$ の範囲で限界変形量以下に収まる。 粘性ダンパーにおいては一定以上にダンパー量を増やすことで基準 変形量を満たすが，弾塑性ダンパーにおいては屋根面と壁面の変形 角が背反関係にあることから，桁行方向で基準変形量を満たすのは 限られた範囲のダンパー量となっている。

屋根面ブレースを弾性とした各モデルの屋根面伝達荷重を文献

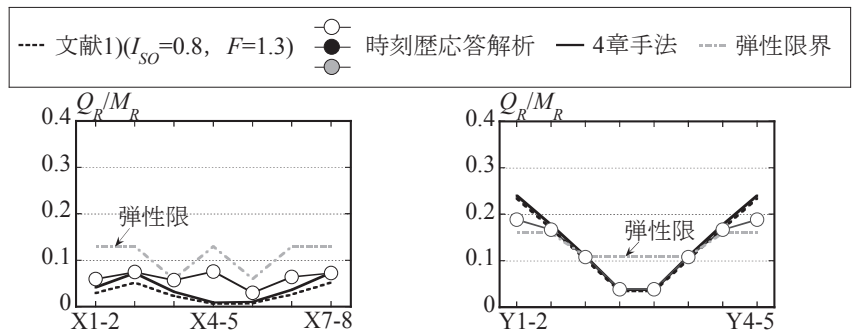

(a-2) 桁行方向

(a) 無補強モデル

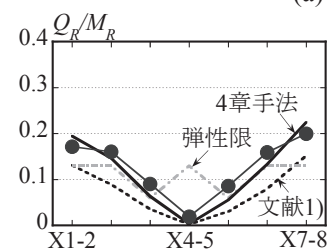

(b-1) 梁間方向

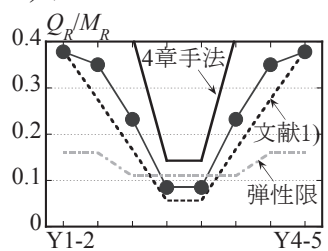

(b-2) 桁行方向 (b) 強度型補強モデル
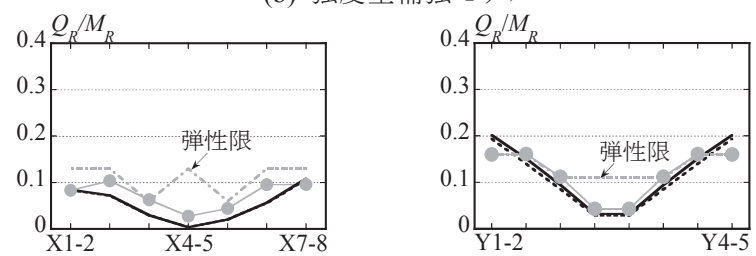

(c-1) 梁間方向 $\left(\mathrm{FA}_{\mathrm{H}}-0.5-1000-\mathrm{B}_{\mathrm{E}}\right) \quad(\mathrm{c}-2)$ 桁行方向 $\left(\mathrm{FA}_{\mathrm{H}}-20-1000-\mathrm{B}_{\mathrm{E}}\right)$ (c) 弾塑性ダンパー付加モデル

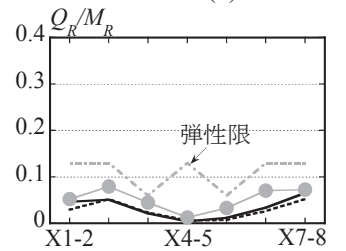

(d-1) 梁間方向 $\left(F^{-}-0.1-B_{E}\right)$

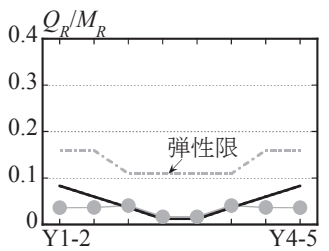

(d-2) 桁行方向 $\left(F_{-}-0.2-B_{E}\right)$ (d) 粘性ダンパー付加モデル

図 11 屋根面伝達荷重（既存屋根面ブレース） 
1)による評価と併せて図 11 に示す。(b)の強度型補強モデルの伝達 荷重は文献 1)による評価を上回っており, これは下部構造の剛性 上昇による屋根部の応答増幅によるものと考えられる。(c),(d)の適 切なダンパー量の制振補強モデルでは応答低減効果により屋根面に 作用する地震力が低減され, 伝達荷重が既存屋根面ブレースの弾性 域内に低減されている。

\section{4. 屋根面伝達荷重の評価}

文献 11)にならい屋根部の簡易応答評価法を用い, 屋根面伝達荷 重の評価を試みる。本応答評価手法は, 屋根面架構と下部構造を一 体とした質点系の応答加速度に屋根部の増幅率および加速度分布を 乗じることで評価するものである ${ }^{17)}$, ${ }^{18)}$ 。水平応答増幅率 $F_{H}$ およ び鉛直応答増幅率 $F_{V}$ は, 屋根部の逆対称 1 波モードに対する等価 2 質点系の固有周期比 $R_{T}=T_{e q} / T_{R}$ および 2 章で定義した $\theta$ より式(4) (7)で与えられる。また本研究では等価固有周期 $T_{e q}$ は, 図 12(2)に見 るように屋根を剛体とした等価 2 質点系の固有值解析および図 5 の 設計用応答スペクトルにおいて最上部質点の応答が最も卓越する モードの固有周期とする。

梁間方向の応答増幅率 :

$$
\begin{aligned}
& F_{H}=\left\{\begin{array}{cc}
3 / 2 & \left(0<R_{T} \leq 1 / 4\right) \\
1 / 2\left(\sqrt{1 / R_{T}}+1\right) & \left(1 / 4<R_{T} \leq 1\right) \\
1 & \left(1<R_{T}\right)
\end{array}\right. \\
& F_{V}=\left\{\begin{array}{cc}
3 C_{V} \theta & \left(0<R_{T} \leq 5 / 16\right) \\
\left(\sqrt{5 / R_{T}}-1\right) C_{V} \theta & \left(5 / 16<R_{T} \leq 5\right) \\
0 & \left(5<R_{T}\right)
\end{array} \text { ただし, } C_{V}=1.33\right.
\end{aligned}
$$

桁行方向の応答増幅率 :

$$
\begin{aligned}
& F_{H}=\left\{\begin{array}{cc}
5 / 2 & \left(0<R_{T} \leq 8 / 25\right) \\
\sqrt{2 / R_{T}} & \left(8 / 25<R_{T} \leq 2\right) \\
1 & \left(2<R_{T}\right)
\end{array}\right. \\
& F_{V}=\left\{\begin{array}{cc}
3 C_{V} \theta & \left(0<R_{T} \leq 3 / 16\right) \\
\left(\sqrt{3 / R_{T}}-1\right) C_{V} \theta & \left(3 / 16<R_{T} \leq 3\right) \\
0 & \left(3<R_{T}\right)
\end{array} \text { ただし, } C_{V}=0.90\right.
\end{aligned}
$$

梁間方向では屋根質量に対する等価 1 質点系の質量比 $R_{M}=M_{e q} / M_{R}$ が大きいほど $R_{T}=1.0$ 付近で共振により水平方向, 鉛直方向とも屋 根部応答が増大寸る。この影響を考慮するため梁間方向の $R_{M}>1.2$ かつ $0.5<R_{T}<1.5$ では $F_{H}, F_{V}$ に代わり下式(8),(9)を使用する。

$$
\begin{aligned}
& F_{H}^{\prime}=\sqrt{F_{H}{ }^{2}+\frac{1}{\left(1-R_{T}^{2}\right)^{2}+\left(1 / R_{M}\right)^{\theta}}} \\
& F_{V}^{\prime}=\sqrt{F_{V}{ }^{2}+\frac{1}{\left(1-R_{T}^{2}\right)^{2}+\left(1 / R_{M}\right)}}
\end{aligned}
$$

式(4)〜 (9)より得られた $F_{H}, F_{V}$ より屋根各部の水平応答加速度分布 $A_{H}(x, y)$, 鉛直応答加速度分布 $A_{V}(x, y)$ は下式 $(10) \sim(13)$ で与えられる。 なお，座標系は屋根中央を原点とする。

梁間方向：

$$
A_{H}(x, y)=A_{e q}\left\{1+\left(F_{H}-1\right) \cos \pi\left(\frac{x}{L_{x}}\right)\right\}
$$

$$
A_{V}(x, y)=A_{e q} F_{V} \cos \pi\left(\frac{x}{L_{x}}\right) \sin \pi\left(\frac{2 y}{L_{y}}\right)
$$

桁行方向：

$$
\begin{aligned}
& A_{H}(x, y)=A_{e q}\left\{1+\left(F_{H}-1\right) \cos \pi\left(\frac{y}{L_{y}}\right)\right\} \\
& A_{V}(x, y)=A_{e q} F_{V} \cos \pi\left(\frac{y}{L_{y}}\right) \sin \pi\left(\frac{2 x}{L_{x}}\right)
\end{aligned}
$$

ここに, $A_{e q}$ は屋根を剛体とみなした時の屋根部の水平応答加速度 である。各層を質点とした 2 質点系の固有值解析を行い, BRI-L2 を用いた SRSS 法より得られる最上部質点の応答加速度とする。

弾塑性ダンパーを用いる場合は SRSS 法による各層の応答変位か ら塑性率 $\mu_{d}$ の収斂計算を行い，等価線形化手法を用いて式(14)により 等価減衰定数 $h_{e q}$ を算定し, 式(15)より応答低減係数 $D_{h}{ }^{15)}$ を求める。

$$
\begin{aligned}
& h_{e q i}{ }^{(1)}=h_{0}+\frac{2\left(1+K_{d i} / K_{f i}\right)}{\pi \mu_{i}^{(0)}} \ln \frac{\mu_{i}^{(0)}+K_{d i} / K_{f i}}{\left(1+K_{d i} / K_{f i}\right) \mu_{i}^{(0) \frac{1}{1+K_{d i} / K_{f f}}}} \\
& D_{h}=\sqrt{\left(1+\alpha h_{0}\right) /\left(1+\alpha h_{e q}\right)} \quad\left(\alpha=75, h_{0}=0.02\right)
\end{aligned}
$$

粘性ダンパーを用いた場合, 等価減衰定数 $h_{e q}$ より一義的に応答低 減係数 $D_{h}$ を求めることができる。

以上により求めた屋根面の水平応答加速度 $A_{H}$ を静的地震荷重係 数とし, 石川 ${ }^{3)}$ の方法を参考に図 12 に示寸鉛直構面ごとの水平 剛性および屋根面剛性ばねで支持された質点モデルにより屋根面伝 達荷重を評価する。なお, 地震荷重が下部構造の保有水平耐力を上 回った場合は，下部構造がそれ以上の荷重を負担できず伝達荷重も 増加しなくなるため, 保有水平耐力の和を $A_{H}$ の分布で配分し, 屋 根面の伝達せん断力を求める。

本章による評価值を前述の図 11 中に実線で示寸。時刻歴応答解 析に比べ，強度型補強モデルの桁行方向でやや過大評価となるもの の，屋根部の応答増幅を考慮することで文献 1)の手法と比較し概 ね安全側で評価できていることがわかる。

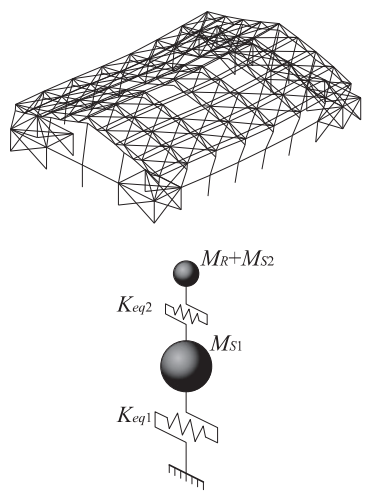

(1)各層の水平剛性 $K_{i}$ 各構面の軒高での水平剛性 $K_{S i}$ 屋根面の面内剛性 $K_{R i}$ 各層, 各構面の重量を算定

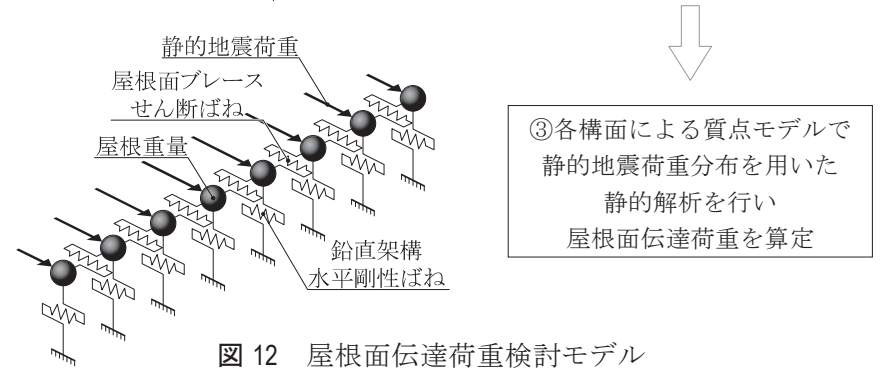




\section{5. 制振部材履歴の最適化}

これまでの分析により制振部材により屋根面伝達荷重の低減を期 待できることが明らかになった。そこで既存屋根面ブレースを取り 換えずに, 要求される耐震性能を満たす改修を目標とし，4 章の評 価手法を用いて屋根部応答を最小とする制振部材履歴の最適解を求 める。弾塑性ダンパーの部材履歴はダンパー剛性比 $K_{d} / K_{f}$, ダン パー降伏変形角 $\phi_{d y}$ の 2 变数によって定められる。この 2 変数をパ ラメータとし，最適化問題を以下のように構成する。

目的関数 : Minimize $A_{\max }\left(K_{d} / K_{f}, \phi_{d y}\right)=\sqrt{A_{H}{ }^{2}+A_{V}{ }^{2}}$

制約条件： subject to $\phi<1 / 100$

(17), $\quad Q_{r} / Q_{r y}<1.0$

ここに, $A_{\max }$ は最大応答加速度, $\phi$ は層間変形角, $Q_{r}$ は屋根面伝達荷 重, $Q_{r y}$ は屋根面の降伏耐力とする。

最適化手法には滑降シンプレックス法を用いる ${ }^{19)}$ 。層間変形角 および屋根面伝達荷重に対しペナルティ関数を定めることで, 制約条件 内での最適解を探索する。最適化過程における各パラメータの変化 を図 13 に示す。(a-1), (b-1)に見るように応答加速度が低下寸る過 程で，(a-2)，(b-2)の層間変形角は増大寸る。梁間方向では制約条件 の有無に関わらず等しい最適解となるが，桁行方向では主架構の剛 性が低いため，(b-2)に見るように制約条件である層間変形角の境 界で制限され, 制振部材が決定されている。屋根面伝達荷重は屋根 応答加速度の低減に応じて同様に低減され, 既存屋根面ブレースで も両方向で降伏耐力内となっていることがわかる。以上の解析より， 本モデルにおいて弾塑性ダンパーを用いる場合，梁間方向では $K_{d} / K_{f}=0.84, \phi_{d y}=1 / 1000$, 桁行方向では $K_{d} / K_{f}=17.5, \phi_{d y}=1 / 1000$ が最 適な剛性比，降伏変形角となる。

得られた最適制振部材履歴による時刻歴応答解析を行い，その結 果得られた加速度および変形角分布を図 14 に示す。強度型補強に 比べ応答加速度は低減されており, 層間変形角, 屋根構面間変形角 ともに 1/100 以内に収まっていることがわかる。このように，制振 部材を下部構造に適切に配置することで, 屋根面ブレースを付加, または取替えることなく下部構造の耐震性能の向上が図れることが 確認された。

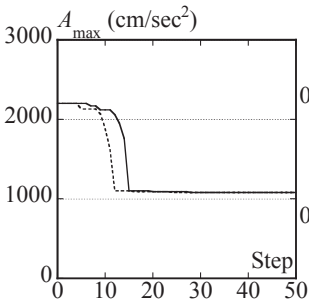

(a-1) 屋根応答加速度
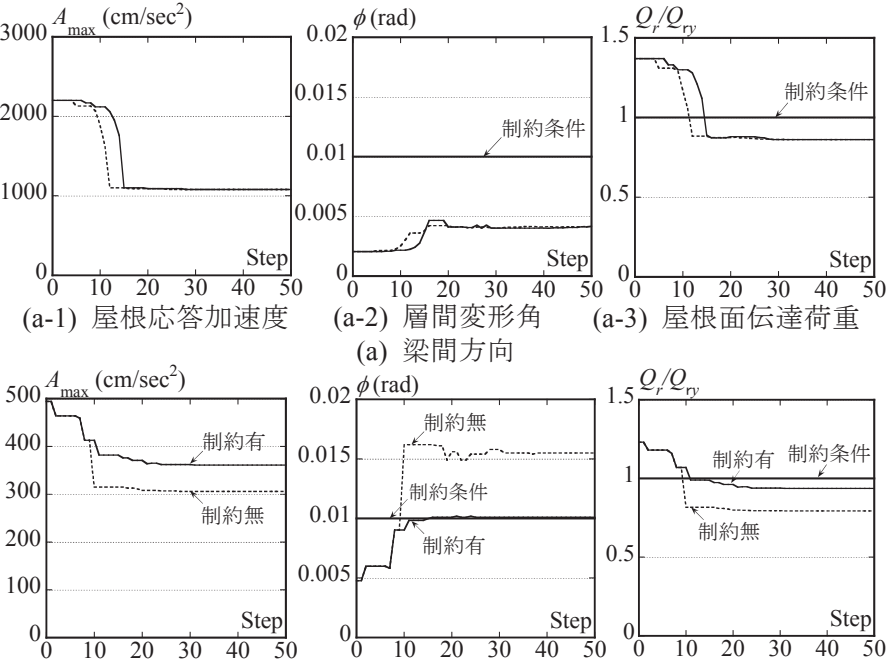

(a-2) 層間変形角
(a) 梁間方向

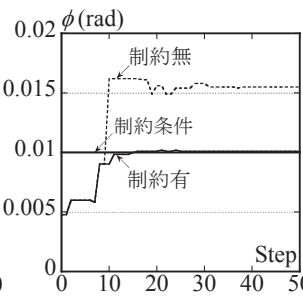

(b-1) 屋根応答加速度

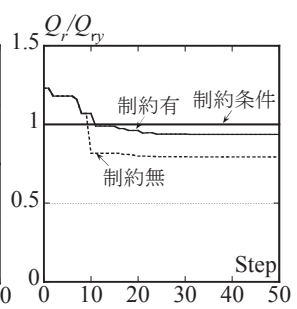

(b-3) 屋根面伝達荷重

(b) 桁行方向

図 13 最適化過程での各パラメータの変化
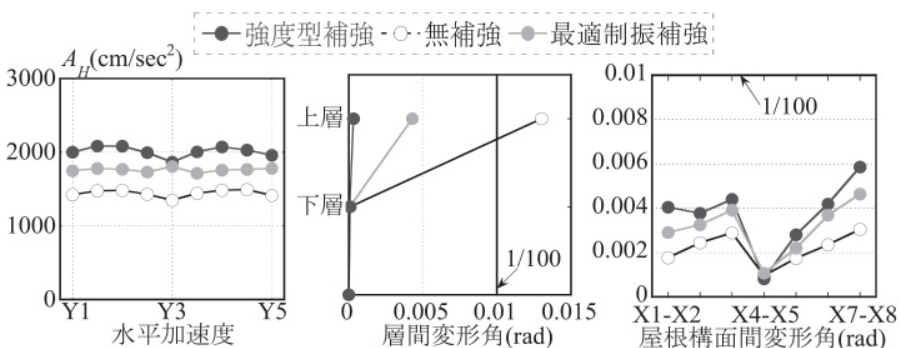

(a) 梁間方向
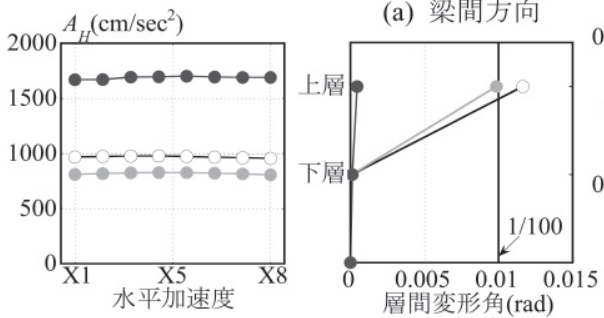

(b) 桁行方向

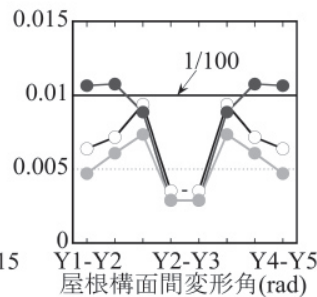

図 14 最適制振部材履歴による時刻歴応答解析結果

\section{6. 構造耐震指標 $I_{\mathrm{SO}}$ による伝達荷重評価の検討}

最後に文献 11$)$ にならい構造耐震判定指標 $I_{S O}$ を用いて屋根面伝 達荷重を簡便に評価する手法の検討を行う。目標耐震性能である $I_{S O}$ に相当する等価 1 質点系応答加速度 $A_{e q}$ を式(19)で表わす。

$$
A_{e q}=\frac{I_{S O} \cdot D_{h}^{(1)}}{F_{f}} \cdot\left(g \cdot F_{e s} \cdot Z \cdot R_{t} \cdot A_{i}\right)
$$

ここに, $g$ は重力加速度であり $, F_{e s}=1.0, F_{f}=1.0$ とする。

弾塑性ダンパーを用いた場合, $I_{S O}$ より一方向載荷での弾性応答せ 儿断力 $Q_{E}$ (図 15 中式(20))を定め, 歪エネルギーの釣合いより想定 地震入力における塑性率 $\mu_{d}$ (式(21)), 等価減衰定数 $h_{e q}$ (式(22)), 応 答低減係数 $D_{h}{ }^{(1)}\left(\right.$ 式(23)) を算定する。式(21)中の $D_{h}{ }^{(0)}$ は, 文献 11) で 提案されている制振部材を用いた際の耐震性能評価手法の過程で得 られる主架構弾性限界時の応答低減係数である。等価 1 質点系応答 加速度 $A_{e q}$ を用いて式(10)(12)から水平応答加速度分布を算定し, 図 12 の質点モデルにより屋根面伝達荷重を評価する。

図 5 に示寸入力を用いた時刻歴応答解析に対し， $I_{S O}=0.8$ とした提 案評価手法による応答加速度の精度を図 16 に，屋根面伝達荷重の精 度を図 17 に示寸。高次振動モード等の影響により屋根面応答加速度 はややばらつきが見られるが、屋根面の伝達荷重は概ね良い対応を 示寸。これは屋根面伝達荷重では構面内の荷重の平均化により

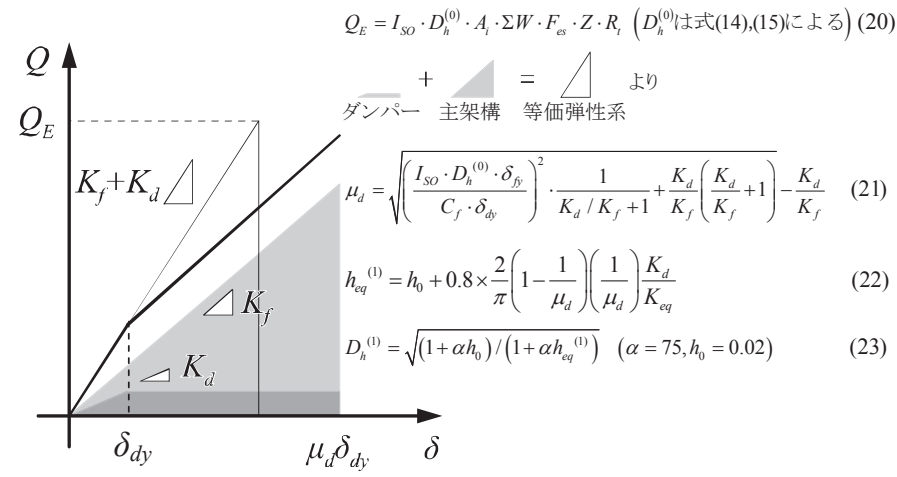

図 15 弾塑性ダンパー付加モデルの塑性率 $\mu$ の評価 


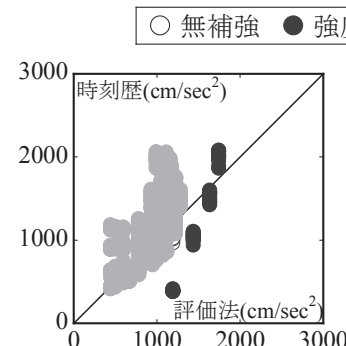

(a-1) 水平応答加速度
強度型補強 ○制振補強

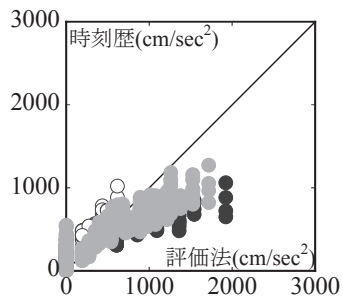

(a-2) 鉛直応答加速度 (a) 梁間方向

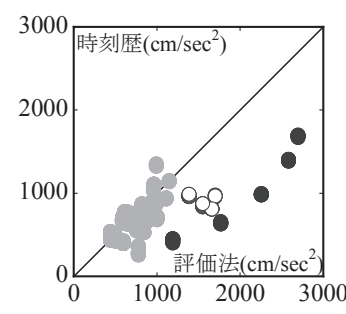

(b-1) 水平応答加速度

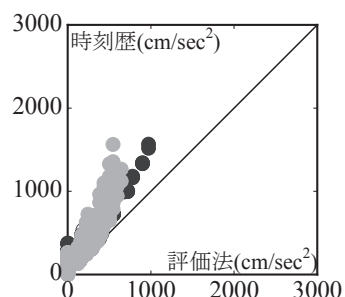

(b-2) 鉛直応答加速度 (b) 桁行方向

図 16 応答加速度評価の精度

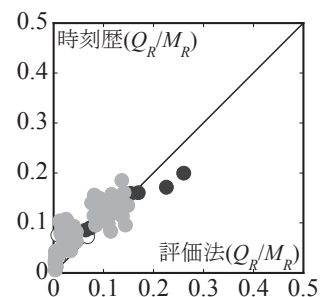

(a) 梁間方向

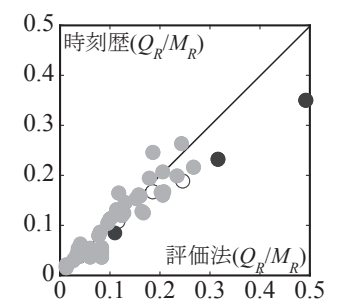

(b) 桁行方向
図 17 屋根面伝達荷重評価の精度

高次モードの影響が除去される為と考えられる。以上より、本節で 提案する手法でも屋根部応答増幅と制振部材の効果を考慮した屋根 面架構の構造性能の検討が可能と考えられる。

\section{7. 結}

既存不適格の学校体育館について, 屋根ブレースの塑性化が主架 構に与える影響を確認し, 各種の改修方法における屋根ブレースの 伝達荷重を分析した。得られた知見を以下に示す。

1) 屋根面の改修を行わずに下部構造に強度型補強を施した場合は, 下部構造の耐力, 剛性の増加に伴い屋根面ブレースの負担が増 加し, 屋根面ブレースのたわみおよび塑性変形の進行により桁 行方向では過大な構面間変形角が生じる。

2) 制振部材を用いる場合, 最大層間変形角は弾塑性ダンパー, 粘 性ダンパーともにダンパー量を大きくするにつれ低減される一 方, 屋根面の伝達荷重は粘性ダンパーでは低減されるが, 弾塑 性ダンパーでは増加寸る傾向が見られる。

3）適切なダンパー量の制振部材を用いることで屋根面伝達荷重を 低減し, 既存の屋根面ブレースを交換せずに耐震性能を向上さ せる改修が可能である。また, 屋根部応答を最小とする制振部 材剛性, 降伏変形角の最適化を行うことで, 既存の屋根面ブ レースにおいても要求される耐震性能が確保できる制振部材の 解が求まることを確認した。
4) 屋根部の応答増幅率と等価線形化手法により静的地震荷重係数 を評価し，構面ごとの質点モデルに入力することで屋根面の伝 達荷重を評価する手法を提案し，安全側の評価となることを確 認した。

5） 4）の手法に加え, 構造耐震判定指標 $I_{S O}$ から屋根面の伝達荷 重を評価する手法を提案し，本手法による評価值と時刻歴応答 解析の結果が概ね良い対応を示すことを確認した。

\section{参考文献}

1) 文部科学省：屋内運動場等の耐震性能診断基準，（社）文教施設協会， 2006. 9

2)（社）日本建築防災協会 : 既存学校体育館等の耐震改修の手引と事例, 2004. 8

3) 石川浩一郎，田村公一：多雪地に建つ大スパン屋根構造における梁間方 向の地震荷重伝達性能, 日本建築学会構造系論文集, 第 560 号, pp125$131,2002.10$

4) 加藤史郎，高金金，山下哲郎，石川浩一郎：円筒状屋根構造における屋根 面ブレースと妻面ブレースの耐震性能向上の役割に関するエネルギー的 考察，鋼構造論文集，第 44 号，pp.83-96，2004.12

5) 福島惊伍，中澤祥二，加藤史郎：体育館等の桁行ブレースの残存圧縮而 力の耐震性に対する効果に関する基礎的研究, 日本建築学会大会学術講 演梗概集（北陸），B-1 分冊，pp.781-782，2010.9

6) 松下千裕，Dinh Thi Thu Ha，石川浩一郎：学校体育館等における水平構 造要素による張間方向鉛直架構の変形制御 その 1 . 水平及び鉛直構造 要素のモデル化と変形及び軸力等の簡易計算法の提案, 日本建築学会大 会学術講演梗概集 (北陸)，B-1 分冊，pp.795-796，2010.9

7) 鈴木真理恵, 松本由香 : 鉄骨造体育館の屋根の面内変形に関寸る静的弾 塑性解析, 日本建築学会大会学術講演梗概集 (北陸), C-1 分冊, pp.1143-1144, 2010.9

8) 日本建築学会 : セミナー「学校体育館の耐震診断・改修手法の課題と取 り組み」資料，2010.12

9) 日本建築学会シェル・空間構造耐震性能小委員会 : 学校体育館等の耐震 性能設計ガイドライン (案), 2008.3

10）清水友香子、源栄正人、石田寛：地震リスクにおける構造一非構造の寄 与に着目した建築物の耐震性能評価、日本建築学会構造系論文集、第 75 巻, 第 658 号, pp.2125-2132, 2010.12

11）竹内徹，堤友紀，熊谷知彦，小河利行：制振部材を用いた鉄骨造学校体 育館の耐震改修および屋根部の地震応答, 日本建築学会構造系論文集, 第 75 巻，第 656 号，pp.1891-1900，2010.10

12）柴田道生，中村武，若林實：鉄骨筋違の履歴特性の定式化－その 1 定 式化関数の誘導 - , 日本建築学会論文報告集，第 316 号，pp.18-23， 1982.6

13) 柴田道生, 若林實 : 鉄骨筋違の履歴特性の定式化 - その 2 応答関数一 の適用 - ，日本建築学会論文報告集，第 320 号，pp.29-34，1982.10

14) 建設省建築研究所: 設計用入力地震動作成手法, 建築研究資料, 第 83 号 1994.11

15) 笠井和彦，伊藤浩資，渡辺厚：等価線形化手法による一質点弾塑性構造 の最大応答予測法, 日本建築学会構造系論文集, 第 571 号, pp.53-62, 2003.9

16）学校施設の耐震補強マニュアル S 造屋内運動場編，文部科学省，2003 年改訂版, 2008.9

17）竹内徹, 小河利行, 山形智香, 熊谷知彦:支持架構付き屋根型円筒ラチス シェルの地震応答評価、日本建築学会構造系論文集、第 596 号, pp.57-64, 2005.10

18）鈴木泉、竹内徹、小河利行、熊谷知彦：桁行方向に地震動を受ける支持 架構付き屋根型円筒ラチスシェルの応答評価、日本建築学会大会学術講 演梗概集（関東），B-1 分冊，pp.753-754, 2006.9

19) Nelder, John A.; R. Mead: A simplex method for function minimization, Computer Journal 7, pp.308-313, 1965

(2011年 5 月 7 日原稿受理, 2011年 8 月 9 日採用決定) 